\title{
Analysis of feline calicivirus capsid protein genes: identification of variable antigenic determinant regions of the protein
}

\author{
Bruce S. Seal, ${ }^{1 * \dagger}$ Julia F. Ridpath $^{2}$ and William L. Mengeling ${ }^{1}$ \\ ${ }^{1}$ Virology Swine Research Unit and ${ }^{2}$ Virology Cattle Research Unit, National Animal Disease Center, USDA, \\ Agricultural Research Service, P.O. Box 70, 2300 Dayton Avenue, Ames, Iowa 50010, U.S.A.
}

Three isolates of feline calicivirus (FCV) designated $\mathrm{NADC}, \mathrm{KCD}$ and $\mathrm{CFI} / 68$ were compared for biochemical, serological and genetic variation within the capsid protein gene. The $M_{\mathrm{r}}$ of the capsid protein from purified virions was approximately 66000 for the NADC virus isolate, which differed slightly from the relative mobilities of the purified capsid proteins of the KCD and CFI/68 isolates. Polyclonal antisera from either cats infected or rabbits hyperimmunized with the CFI/68 isolate cross-reacted with all three isolates by Western blot analysis. However, these polyclonal antisera to CFI/68 varied considerably in their virus-neutralization titres to the KCD and NADC isolates. Nucleotide sequence data confirmed the genetic variability among these FCV isolates. Comparison of the predicted amino acid sequence of the capsid protein among isolates revealed two regions of sequence divergence that probably contain the antigenically variable determinants. These hypervariable regions may vary by as much as $55 \%$ among isolates of FCV. The amino acid sequence diversity in the hypervariable regions of the $K C D$ and NADC isolates correlated well with the virusneutralization data and suggests that polyvalent vaccines may be more protective than the commonly used monovalent vaccines.
Feline caliciviruses (FCVs) are associated with respiratory disease in cats which, in most cases, is limited to the upper respiratory tract. The disease ranges from inapparent infection or mild disease to severe respiratory disease and pneumonia. Ulcerations occur in the oral cavity and viral shedding may persist from the nasal and pharyngeal region for 2 weeks post-infection (p.i.) (Kahn \& Gillespie, 1971; for review, see Gillespie \& Scott, 1973). Investigators analysing FCV isolates from the U.K., U.S.A., Australia and New Zealand have demonstrated that substantial variation exists in serum crossneutralization among most virus isolates examined (Bittle et al., 1960; Crandell, 1967; Povey, 1974; Kalunda et al., 1975; Burki et al., 1976). Isolates of FCV also differ among one another in plaque morphology (Ormerod \& Jarrett, 1978) and in cross-reactivity to monoclonal antibodies (MAbs) (Carter et al., 1989; Toya et al., $1991 a$ ). It has recently been postulated that variant

$\uparrow$ Present address: Southeast Poultry Research Laboratory, USDA, Agriculture Research Service, 934 College Station Road, P.O. Box 5657, Athens, Georgia 30604, U.S.A

Nucleotide sequence data reported in this paper appear in the GenBank database under the accession numbers L09718 (NADC isolate) and L09719 (KCD isolate). strains resistant to current vaccination procedures may be emerging (Knowles et al., 1990).

Structurally, FCV isolates are non-enveloped with a positive-strand, polyadenylated RNA genome of $7.69 \mathrm{~kb}$ in size with a single capsid protein (Carter et al., 1992a). The viral genome codes for a picornavirus-like RNAdependent RNA polymerase, cysteine protease, a $2 \mathrm{C}$ polypeptide and, similar to picornaviruses, the RNAdependent RNA polymerase is located at the $\mathrm{C}$ terminus of the putative non-structural polypeptides (Neill, 1990; Carter et al., 1992a). During replication, a nested set of $3^{\prime}$ coterminal transcripts are produced. The most abundant transcript is a $2.4 \mathrm{~kb}$ subgenomic RNA which can be detected as early as $2 \mathrm{~h}$ p.i. (Neill \& Mengeling, 1988; Carter, 1990) and has been identified as the transcript encoding the viral capsid protein (Neill et al., 1991). The capsid protein gene has been sequenced for the CFI/68 isolate (Neill et al., 1991), the F4 isolate (Toya et al., 1991b) and F9 isolate (Carter et al., $1992 a, b)$ of $\mathrm{FCV}$. Although the majority of the protein is highly homologous among isolates, one domain of the polypeptide from residues 396 to 525 of the $\mathrm{F} 9$ isolate varies in amino acid sequence by $25 \%$ from the same region of the CFI/68 isolate (Carter et al., 1992b). A major portion of this area of the capsid protein has since been designated region $\mathrm{E}$ among caliciviruses (Neill, 
Table 1. One-way cross-neutralization of four FCV isolates using sera obtained from a cat and rabbit preand post-inoculation with $C F I / 68$

\begin{tabular}{|c|c|c|c|c|c|c|c|c|}
\hline & \multicolumn{2}{|c|}{$\mathrm{CFI} / 68^{*}$} & \multicolumn{2}{|c|}{$\mathrm{KCD}^{*}$} & \multicolumn{2}{|c|}{ NADC* } & \multicolumn{2}{|c|}{$\mathrm{F} 9 *$} \\
\hline & Pre & Post & Pre & Post & Pre & Post & Pre & Post \\
\hline Cat $2669 \dagger$ & $<2$ & 512 & $<2$ & 128 & $<2$ & $<8$ & $<2$ & 128 \\
\hline Rabbit $101 \dagger$ & $<2$ & 4096 & $<2$ & 32 & $<2$ & $<8$ & $<2$ & 2048 \\
\hline
\end{tabular}

* FCV isolates CFI/68, KCD and F9 were obtained from the ATCC. Isolate NADC was obtained from a healthy cat at the Ames, Iowa, animal shelter.

$\dagger$ Reciprocal virus neutralization titres of twofold dilutions of sera from cats and rabbits inoculated with the CFI/68 isolate of FCV, based on $100 \%$ plaque reduction of 100 p.f.u., in triplicate.

1992) and may contain the antigenically variable determinants as suggested by both these investigators. Because FCV isolates may vary considerably in serum crossneutralization among isolates and amino acid sequence variation occurs in the capsid protein, three isolates of FCV, one of which was antigenically distinct by one-way serum cross-neutralization, were compared for biochemical and genetic variation within the capsid protein genes.

The FCVs used during these studies were replicated in Crandell-Reese feline kidney cells (Crandell et al., 1973) and purified in caesium chloride gradients at a density of $1.37 \mathrm{~g} / \mathrm{ml}$ (Love \& Jones, 1974; Komolafe et al., 1981). Antisera prepared as described by Povey (1979) against the FCV CFI/68 isolate (Crandell et al., 1960) in both cats and rabbits were used for Western blot analysis and serum virus neutralization of heterologous FCV isolates KCD (Fastier, 1957), F9 (Bittle et al., 1960) and a recently obtained isolate designated NADC. When an adult seronegative cat was inoculated with the FCV isolate CFI/68, no clinical symptoms were observed. However, sera from this animal had a high neutralizing titre to the CFI/68 isolate, whereas the neutralizing titre to the more recent FCV isolate NADC was essentially non-existent. The cat anti-CFI/68 serum had a neutralizing titre to the $\mathrm{KCD}$ and $\mathrm{F} 9$ isolates that was intermediate to the CFI/68 and NADC isolates (Table 1). When a rabbit was hyperimmunized with purified FCV CFI/ 68 capsid protein a stronger antibody response was obtained (Table 1). The rabbit anti-CFI/68 serum had high neutralizing titres to the CFI/68 and F9 isolates as compared to the titres obtained for the KCD and NADC isolates (Table 1). Again, the titre to the KCD isolate was intermediate to the CFI/68 and NADC isolate's serum-virus neutralization titres.

After the capsid proteins from three different FCV isolates were separated by SDS-PAGE (Hames et al., 1981), a slight difference in relative mobilities of the capsid proteins from each individual isolate was ob- served. The FCV NADC isolate had a capsid protein of slightly greater size than the KCD isolate which was slightly larger than the CFI/68 isolate (Fig. 1a). In separate gels, the proteins were transferred (Towbin et $a l ., 1979)$ to nitrocellulose and reacted with either cat or rabbit antisera to CFI/68 using anti-species conjugate to detect primary antibody (Gershoni \& Palade, 1983). The capsid proteins from all three FCV isolates reacted positively with no differences in reactivities among these isolates (Fig. $1 b$ ). The results of the Western blot analysis demonstrates that there are many linear epitopes shared among the FCV capsid proteins. However, based on the serum-virus neutralization data, the neutralizing epitopes may be highly variable.

Poly(A) RNA isolated at $6 \mathrm{~h}$ p.i. (Chirgwin et al., 1979; Glisin et al., 1974; Aviv \& Leder, 1972) was used to construct cDNA libraries (Gubler \& Hoffman, 1983) to the CFI/68, KCD and NADC FCV isolates using a NotI-SalI primer-adaptor system (Bethesda Research Laboratories; Kotewicz et al., 1988; D'Alessio \& Gerard, 1988). The cDNA libraries were amplified in DH10B (Hanahan, 1985), and mini-preparations for plasmid purification (Zhou et al., 1990) were completed and screened under low stringency hybridization conditions using a radioactively labelled (Feinberg \& Vogelstein, 1983, 1984), previously cloned CFI/68 cDNA capsid gene (Neill et al., 1991). Positive clones were identified from each isolate that contained inserts from 2.5 to $3 \cdot 1 \mathrm{~kb}$ in size. The $3^{\prime} 2400$ bases of a $3 \cdot 1 \mathrm{~kb}$ cDNA clone from the NADC isolate and a $3.0 \mathrm{~kb}$ cDNA clone of the $\mathrm{KCD}$ isolate were sequenced (Tabor \& Richardson, 1987; Sanger et al., 1977) using an automated nucleic acid sequencer (Smith et al., 1986; Prober et al., 1987). When compared to the published sequence of the CFI/ 68 isolate of FCV (Neill et al., 1991), the nucleotide sequences of the NADC and KCD isolates were $81 \%$ and $79 \%$ similar to the $\mathrm{CFI} / 68$ isolate. The nucleotide sequences were confirmed by sequencing through each area of the genome at least three times using oligonucleotide primers, sequencing of subclones and by sequencing of exonuclease III-generated nested deletions (Henikoff, 1987). Two open reading frames (ORFs) were identified in both the NADC and KCD cDNA clones. The first ORF was 2004 bases in length and codes for the capsid gene of FCV (Neill et al., 1991; Toya et al., $1991 b$; Carter et al., 1992a, b). This large ORF begins at the ATG located at residue 27 of the NADC and KCD nucleotide sequences and ends with the TGA at position 2031. The second ORF was 318 bases in length for both the NADC and KCD isolates. The start site of this ORF overlaps with the capsid gene stope codon at position 2030. The second ORF stop site occurs at nucleotide 2348 which was followed by a small $3^{\prime}$ untranslated region 45 bases long for NADC cDNA or 42 bases in 


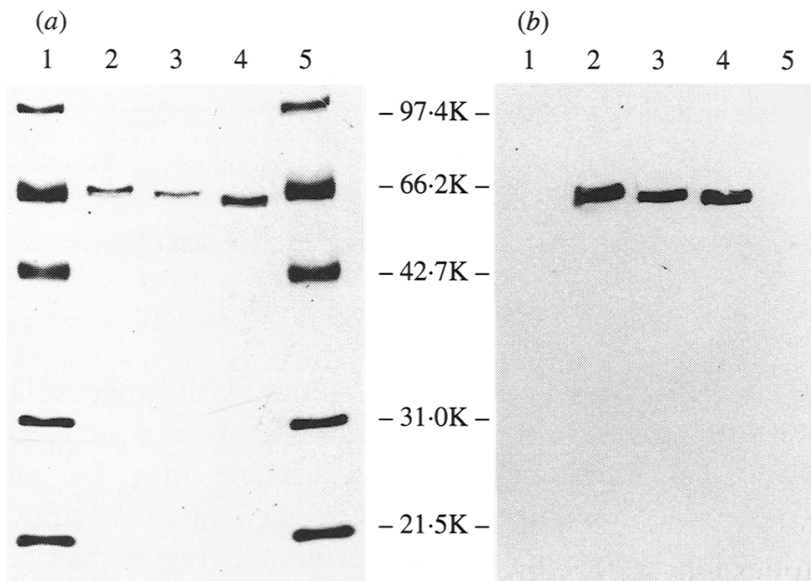

Fig. 1. Analysis of the capsid protein from three different isolates of FCV by SDS-PAGE and Western blot. Isolates were caesium chloride density gradient-purified, solubilized and electrophoresed in 10 to $20 \%$ SDS-polyacrylamide and stained with Coomassie blue (a). Following electrophoresis, the proteins were electroblotted to nitrocellulose paper, incubated with cat antiserum to the CFI/68 isolate, and reacted with horseradish peroxidase-conjugated anti-cat $\operatorname{IgG}(b)$. Lanes 1 and 5 contain $M_{\mathrm{r}}$ markers; lane $2, \mathrm{NADC}$ capsid protein; lane $3, \mathrm{KCD}$ capsid protein; lane $4, \mathrm{CFI} / 68$ capsid protein. $M_{\mathrm{r}}$ marker sizes are indicated.

length for the KCD cDNA. All the cDNA clones from the $\mathrm{CFI} / 68$, NADC and $\mathrm{KCD}$ virus isolates contained approximately 50 adenine residues corresponding to the poly(A) tail.
The derived amino acid sequence for the NADC and $\mathrm{KCD}$ capsid proteins are aligned with the corresponding capsid protein sequences of the CFI/68 (Neill et al., 1991), F4 (Toya et al., 1991b) and F9 (Carter et al., $1992 a, b)$ in Fig. 2. The amino acid sequences of the capsid proteins are 88 to $91 \%$ similar among the five FCV isolates. As proposed by Neill (1992), calicivirus capsid protein sequences were divided into six regions which may be further delineated based on additional sequence information now available. The first region corresponds to residues 1 to 120 for region $\mathrm{A}$, the $\mathrm{NH}_{2}$ terminal portion of the capsid precursor which is theoretically cleaved to produce the functional capsid protein. Region B corresponds to amino acids 121 to 396 and begins with the conserved FRLE-D cleavage sequence. Within region $B$ an important myristylated glycine residue was predicted to occur at position 128 just following the cleavage site of the capsid protein (Grand, 1989; Chow et al., 1987). A putative ATP/GTPbinding site motif (Walker et al., 1982) with the amino acid sequence ADMATGKS was located in the highly conserved $\mathrm{B}$ region of the capsid protein from amino acid residues 154 to 161 . The $\mathrm{C}$ region extends from residues 397 to 401 and is a small island of sequence divergence among FCV capsid proteins. The D region extends from amino acids 402 to 425 and is highly conserved. A region of extensive sequence divergence ranges from residues 426 to 520 . This has been designated
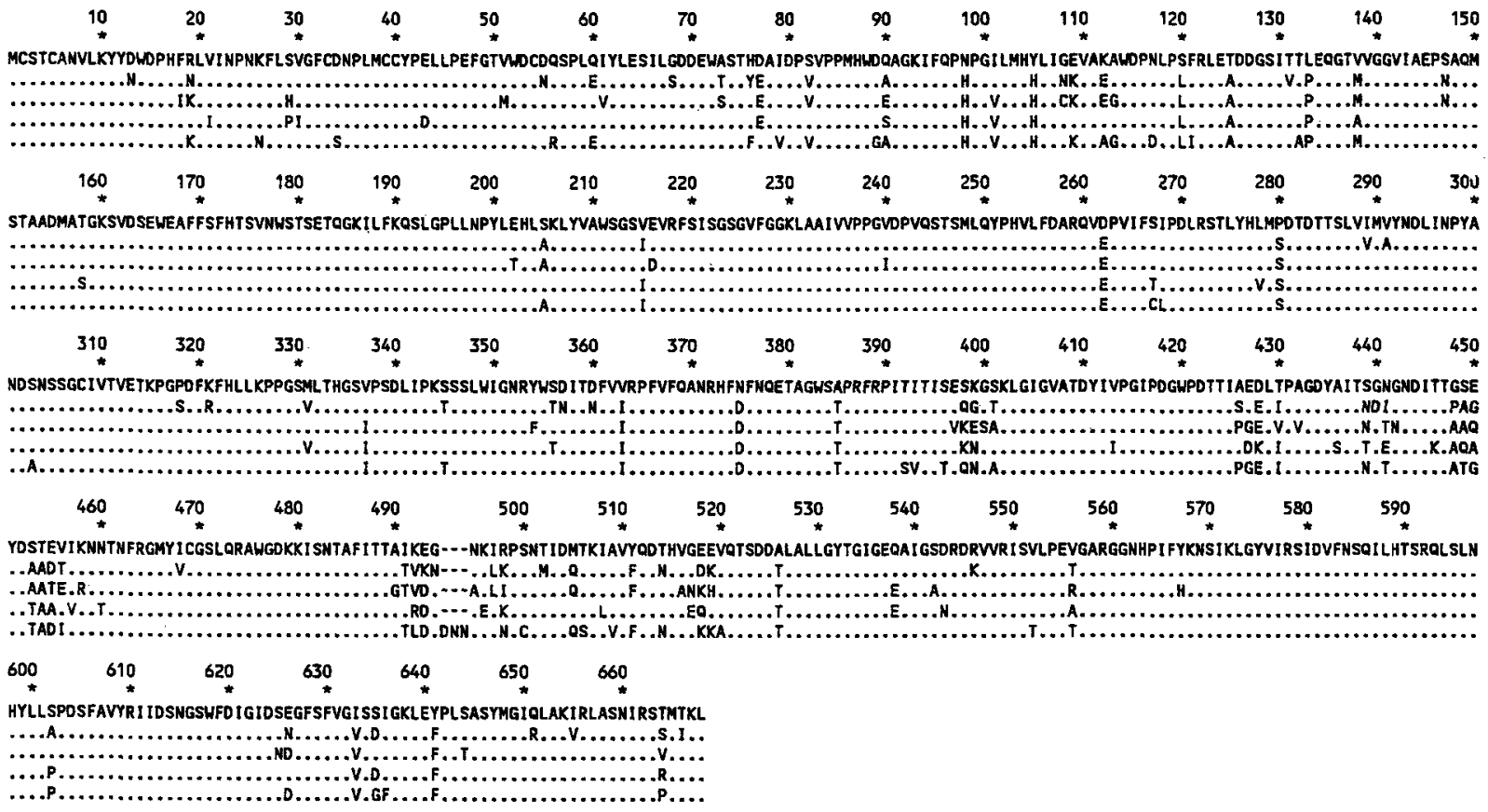

Fig. 2. Comparative analysis of FCV capsid protein amino acid sequences. Sequences of the FCV CFI/68 isolate (Neill et al., 1991), F9 isolate (Toya et al., 1991 b), F4 isolate (Carter, 1992) were obtained from EMBL/GenBank. The FCV NADC and KCD sequences were obtained by sequencing cDNA using fluorescence-labelled dideoxynucleotides and translating the nucleotide sequence (DNASTAR). Sequences were compared by the ALIGN program (Science and Educational Software) based on the methods of Lipman \& Pearson (1985). 


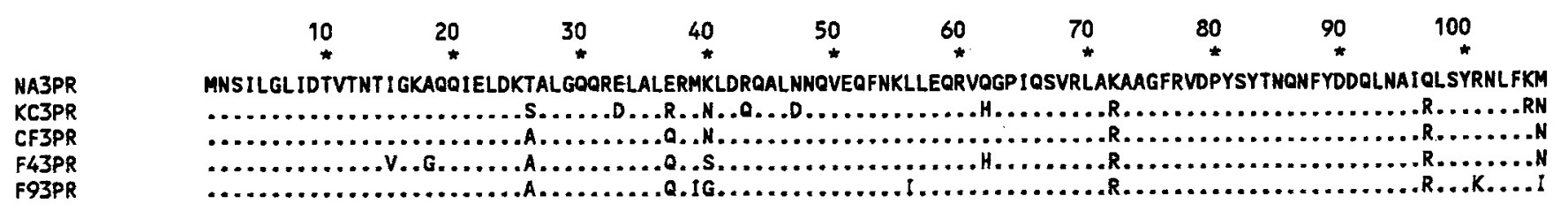

Fig. 3. Comparative analysis of predicted amino acid sequences of the FCV 3 ' protein contiguous with the capsid protein gene. Analysis was conducted as outlined in Fig. 2.

region E (Neill, 1992), which in FCV also contains a highly conserved sequence of 28 amino acids from threonine 461 to threonine 488 surrounded by regions of sequence divergence. The carboxy-terminal region $\mathrm{F}$, extending from residues 521 to 668 of the protein, is highly conserved in amino acid sequence.

The ORF located $3^{\prime}$ to the capsid gene codes for a protein of 106 amino acids with a predicted size of approx. 12200. This predicted small basic protein was 90 to $94 \%$ similar at the amino acid sequence level among the five FCV isolates (Fig. 3). This small highly conserved basic protein has been hypothesized to be a nucleic acidbinding protein (Neill et al., 1991) similar to those found in plant viruses (Koonin et al., 1991).

The capsid protein amino acid sequences are 89 to $91 \%$ similar among the FCV isolates. As proposed by Neill (1992), the capsid protein could be divided into six regions which were further delineated in this report. A domain corresponding to the $\mathrm{E}$ region exhibited sequence divergence at the amino acid level among capsid proteins of FCV isolates. Consequently, the $\mathrm{E}$ region most likely possesses the antigenically variable determinants of the capsid protein. Computer alignment (Fig. 2) of this region demonstrates that the $\mathrm{E}$ region in the $\mathrm{FCV}$ capsid protein has two hypervariable areas, one from residues 426 to 460 , and a second from residues 490 to 520 , surrounding a highly conserved sequence from amino acids 461 to 489 . These were the only areas of the capsid protein which exhibited extensive sequence variation. Hyperimmune sera generated to the CFI/68 isolate partially neutralized the $\mathrm{KCD}$ isolate, but failed to neutralize the NADC isolate. The two hypervariable regions of the $\mathrm{KCD}$ capsid protein are $66 \%$ similar to the CFI/68 capsid protein, and these regions of the NADC capsid protein are only $55 \%$ similar to the CFI/68 isolate. The hypervariable regions of the CFI/68 were $75 \%$ similar to the F9 isolate, a commonly used vaccine strain (Carter et al., 1992a,b). This correlates well with the serological data, and suggests that to induce neutralizing activity to heterologous isolates, an FCV must have at least a $60 \%$ or more sequence similarity within the hypervariable areas of the $\mathrm{E}$ region. The increased variability of the NADC region $E$ lends credence to the hypothesis of Knowles et al. (1990) that there has been a variation in the spectrum of antigenicity among FCVs induced by vaccination with single isolates of the viruses. In agreement with Knowles et al. (1990), some form of a polyvalent vaccine may be more protective than currently used single isolate vaccines.

The F9 calicivirus capsid protein $\mathrm{E}$ region has been expressed (Guiver et al., 1992; Milton et al., 1992) and MAbs produced against this region were neutralizing (Toya et al., 1991 a; Milton et al., 1992). One of the MAbs produced by Milton et al. (1992), 4E7, crossreactive with the $\mathrm{CFI} / 68$ isolate, bound the hypervariable region between residues 422 to 448 . Another MAb, 1G9, not cross-reactive with CFI/68, bound to residues 449 to 458 where the greatest amount of sequence divergence occurred between the F9 and CFI/68 capsid proteins (Milton et al., 1992). These are predicted hydrophilic areas (Kyte \& Doolittle, 1982) of the protein exhibiting a high antigenic index (Jameson \& Wolf, 1988). Consequently, the neutralizing epitopes of FCVs probably exist on the surface of the virus as is the case for human rhinovirus 2 (Appleyard et al., 1990). The hypervariable areas of the $E$ region surround highly conserved amino acids (461 to 489 ) in this same region (Fig. 2). This sequence, conserved in all FCV isolates so far examined, is an area that according to computer analysis (Emini et al., 1985) contains a hydrophilic region of high surface probability surrounded by hydrophobic regions with low surface probability. These conserved amino acids might possibly be involved with virus attachment with the hydrophilic portion surrounded by hydrophobic areas providing a 'canyon' for virus attachment similar to the situation of rhinovirus binding (Rossmann et al., 1985).

The authors credit Ms Deborah Floan for nucleotide sequencing the cDNA clones, Ms Judy Lundy of the Iowa State University Nucleic Acids Facility for oligonucleotide synthesis, Ms Susan Ohlendorf for administrative assistance and typing the manuscript, and $\mathrm{Mr}$ Gene Hedberg, Mr Tom Glasson and Mr Wayne Romp for graphics and photography. The authors thank Dr Roger Johnson, Dr Cyril LutzeWallace, Dr Richard Meyer, Dr Shirley Halling, Dr John Neill and Dr Mark Ackerman for critical review of the manuscript. These studies were supported by U.S.D.A. CRIS number 3630-32000-065-00D.

\section{References}

Appleyard, G., Russell, S. M., Clarke, B. E., Speller, S. A., TROWBRidGe, M. \& VAdOLAS, J. (1990). Neutralization epitopes of human rhinovirus type 2. Journal of General Virology 71, 1275-1282. 
Aviv, H. \& Leder, P. (1972). Purification of biologically active globin messenger RNA by chromatography on oligothymidylic acidcellulose. Proceedings of the National Academy of Sciences, U.S.A. 69, 1408-1412.

Bittle, J. L., York, C. J., Newberne, J. W. \& Martin, M. (1960). Serologic relationship of new feline cytopathogenic viruses. American Journal of Veterinary Research 21, 547-550.

Burki, F., Starustlea, B. \& Ruttner, O. (1976). Attempts to serologically classify feline caliciviruses on a national and international basis. Infection and Immunity 14, 876-881.

CARTER, M. J. (1990). Transcription of feline calicivirus RNA, Archives of Virology 114, 143-152.

Carter, M. J., Routledge, E. G. \& Toms, G. L. (1989). Monoclonal antibodies to feline calicivirus. Journal of General Virology $\mathbf{7 0}$, $2197-2200$

Carter, M. J., Milton, I. D., Meanzer, J., Bennet, M., Gaskell, R. M. \& TURNER, P. C. (1992a). The complete nucleotide sequence of a feline calicivirus. Virology 190, 443-448.

Carter, M. J., Milton, I. D., Turner, P. C., Meanzer, J., Bennet, M. \& GASKelL, R. M. (1992b). Identification and sequence determination of the capsid protein of feline calicivirus. Archives of Virology 122, 223-235.

Chirgwin, J. M., Przybla, A. E., Macdonald, R. J. \& Rutter, W. J. (1979). Isolation of biologically active ribonucleic acid from sources enriched in ribonuclease. Biochemistry 18, 5294-5299.

Chow, M., Newman, J. F. E., Filman, D., Hogle, J. M., Rowlands, D. J. \& BRown, F. (1987). Myristilation of picornavirus capsid protein VP4 and its structural significance. Nature, London 327, $482-486$.

Crandell, R. A. (1967). A description of eight feline picornaviruses and an attempt to classify them Proceedings of the Society for Experimental Biology and Medicine 126, 240-244.

Crandell, R. A., Neimann, W. H., Ganaway, J. R. \& Maurer, F, D. (1960). Isolation of cytopathic agents from the nasopharyngeal region of the domestic cat. Virology 10, 283-285.

Crandell, R. A., Fabricant, C. A. \& Nelson-Rees, W. A. (1973). Development, characterization, and viral susceptibility of a feline (Felis catus) renal cell line (CRFK). In Vitro Cellular and Developmental Biology 9, 176-185.

D'Alessio, J. M. \& GERARD, G. F. (1988). Second-strand cDNA synthesis with $E$. col $i$ DNA polymerase I and RNAseH: the fate of information at the RNA $5^{\prime}$ terminus and the effect of $E$. coli DNA ligase. Nucleic Acids Research 16, 1999-2014.

Emini, E. A., Hughes, J. V., Perlow, D. S. \& Boger, J. (1985). Induction of hepatitis A virus-neutralizing antibody by a virusspecific synthetic peptide. Journal of Virology 55, 836-839.

FASTIER, L. B. (1957). A new feline virus isolated in tissue culture. American Journal of Veterinary Research 18, 382-389.

FeinberG, A. P. \& Vogelstern, B. (1983). A technique for radiolabeling DNA restriction endonuclease fragments to high specific activity. Analytical Biochemistry 132, 6-13.

Feinberg, A. P. \& Vogelstein, B. (1984). Addendum: a technique for radiolabeling DNA restriction endonuclease fragments to high specific activity. Analytical Biochemistry 137, 266-267.

Gershoni, J. M. \& Palade, G. E. (1983). Protein blotting: principles and applications. Analytical Biochemistry 131, 1-15.

Gillespie, J. H. \& ScotT, F. W. (1973). Feline viral infections. Advances in Veterinary Science 17, 163-200.

Glisin, V., Crkvenjakov, R. \& Byers, C. (1974). Ribonucleic acid isolated by cesium chloride centrifugation. Biochemistry 13, 26332637.

GRAND, R. J. A. (1989). Acylation of viral and eukaryotic proteins. Biochemical Journal 258, 625-638.

Gubler, U. \& Hoffman, B. J. (1983). A simple and very effective method for generating cDNA libraries. Gene 25, 263-269.

Guiver, M., LitTler, E., Caul, E. O. \& Fox, A. J. (1992). The cloning, sequencing and expression of a major antigenic region from the feline calicivirus capsid protein. Journal of General Virology 73, 2429-2433.

HAMES, B. D. (1981). An introduction to polyacrylamide gel electrophoresis. In Gel Electrophoresis of Proteins: A Practical Approach, pp. 1-91. Edited by B. D. Hames \& D. Rickwood. Oxford: IRL Press.
Hanahan, D. H. (1985). Techniques for transformation of E. coli. In DNA Cloning: A Practical Approach, vol. I, pp. 109-136. Edited by D. M. Glover. Oxford: IRL Press.

HeNIKOFF, S. (1987). Unidirectional digestion with exonuclease III in DNA sequence analysis. Methods in Enzymology 155, 156-165.

JAMESON, B. A. \& WOLF, H. (1988). The antigenic index: a novel algorithm for predicting antigenic determinants. Computer Applications in the Biosciences 4, 181-186.

KAHN, D. E. \& GILLESPIE, J. H. (1971). Feline viruses: pathogenesis of picornavirus infection in the cat. American Journal of Veterinary Research 32, 521-531.

Kalunda, M., Lee, K. M., Homes, D. F. \& Gillespie, J. H. (1975). Serologic classification of feline caliciviruses by plaque-reduction. American Journal of Veterinary Research 36, 353-356.

Knowles, J. O., Dawson, S., Gaskell, R. M., Gaskell, C. J. \& HARVEY, C. E. (1990). Neutralization patterns among recent British and North American feline calicivirus isolates from different clinical origins. Veterinary Record 127, 125-127.

Komolafe, O. O., JARRETT, O. \& LAIRD, H. M. (1981). Two populations of virus-specific particles released from feline calicivirusinfected cells. Virology 110, 217-220.

Koonin, E. V., Boyko, V. P. \& Dolja, V. V. (1991). Small cysteinerich proteins of different groups of plant RNA viruses are related to different families of nucleic acid-binding proteins. Virology 181, 395-398

Kotewicz, M. L., Sampson, C. M., Dalesio, D. E. \& Gerard, G. F. (1988). Isolation of cloned Moloney murine leukemia virus reverse transcriptase lacking ribonuclease $\mathrm{H}$ activity. Nucleic Acids Research 16, 265-277.

KYTE, J. \& Doolitrle, R. F. (1982). A simple method for displaying the hydropathic character of a protein. Journal of Molecular Biology 157, 105-132.

Lipman, D. J. \& Pearson, W. R. (1985). Rapid and sensitive protein similarity searches. Science 227, 1435-1441.

Love, D. N. \& JoNEs, R. F. (1974). Studies on the buoyant density of a feline calicivirus. Archiv für die gesamte Virusforschung 44, 142-143.

Milton, I. D., Turner, J., Teelan, A., Gaskell, R., Turner, P. C. \& CARTER, M. J. (1992). Location of monoclonal antibody binding sites in the capsid protein of feline calicivirus. Journal of General Virology 73, 2435-2439.

NeILL, J. D. (1990). Nucleotide sequence of a region of the feline calicivirus genome which encodes picornavirus-like RNA-dependent RNA polymerase, cysteine protease and $2 \mathrm{C}$ polypeptides. Virus Research 17, 145-160.

NeILx, J. D. (1992). Nucleotide sequence of the capsid protein gene of two serotypes of San Miguel sea lion virus: identification of conserved and non-conserved amino acid sequences among calicivirus sequences. Virus Research 24, 211-222.

NeILX, J. D. \& Mengeling, W. L. (1988). Further characterization of the viral-specific RNAs in feline calicivirus infected cells. Virus Research 11, 59-72.

Neill, J. D., Reardon, I. M. \& Heinrikson, R. L. (1991). Nucleotide sequence and expression of the capsid protein gene of feline calicivirus. Journal of Virology 65, 5440-5447.

OrMerod, E. \& JARRETT, O. (1978). A classification of feline calicivirus isolates based on plaque morphology. Journal of General Virology 39, 537-540.

POVEY, R. C. (1974). Serologic relationships among feline caliciviruses. Infection and Immunity 10, 1307-1314.

Povey, R. C. (1979). The preparation of a polyvalent feline calicivirus antiserum. Canadian Journal of Comparative Medicine 43, 187-193.

Prober, J. M., Tranor, G. L., Dan, R. J., Hobbs, F. W., Robertson, C. W., ZaGursky, R. J., Cocuzza, A. J., Jensen, M. A. \& BurMEISTER, K. (1987). A system for rapid DNA sequencing with fluorescent chain-terminating dideoxynucleotides. Science 238, 336341 .

Rossmann, M., Arnold, E., Erickson, J., Frankenberger, E., Griffith, J., Hecht, H., Johnson, J., Kamer, G., Luo, M., Mosser, A., Rueckert, R., Sherry, B. \& VRIEnd, G. (1985). Structure of a human common cold virus and functional relationship to other picornaviruses. Nature, London 317, 145-153.

SaNGer, F., Nicklen, S. \& Coulson, A. R. (1977). DNA sequencing 
with chain-terminating inhibitors. Proceedings of the National Academy of Sciences, U.S.A. 74, 5463-5467.

Smith, L. M., Sanders, J. Z., Kaiser, R. J., Hughes, P., Dodd, C., Connell, C. R., Heines, C., Kent, S. B. H. \& Hood, L. E. (1986). Fluorescence detection in automated DNA sequence analysis. Nature, London 321, 673-681.

TABOR, S. \& RichaRdson, C. C. (1987). DNA sequence analysis with a modified bacteriophage T7 DNA polymerase. Proceedings of the National Academy of Sciences, U.S.A. 84, 4767-4771.

Towbin, H., Staehelin, T. \& GoRdon, J. (1979). Electrophoretic transfer of proteins from polyacrylamide gels to nitrocellulose sheets: procedure and some applications. Proceedings of the National Academy of Sciences, U.S.A. 76, 4350-4354.

Toya, Y., Masuoka, K., Takahashi, E. \& Mikami, T. (1991a).
Neutralizing epitopes of feline calicivirus. Archives of Virology 117, 173-181.

Toya, Y., Taniguchi, Y., Takahashi, E., Utagawa, E., Takeda, N., Miyanura, K., Yamazaki, S. \& Mikami, T. (1991 $b$ ). Sequence analysis of the $3^{\prime}$-end of feline calicivirus genome. Virology 183, 810-814.

Walker, J. E., Saraste, M., Runswick, M. J. \& Gay, N. J. (1982). Distantly related sequences in the $\alpha$ and $\beta$ subunits at ATP synthase, myosin, kinases and other ATP-requiring enzymes and a common nucleotide binding fold. EMBO Journal 1, 945-951.

ZhOU, C., YANG, Y. \& JONG, A. Y. (1990). Mini-prep in ten minutes. Biotechniques 8, 172-173.

(Received 12 March 1993; Accepted 9 July 1993) 